\title{
Urinary 5-hydroxyindoleacetic acid in 8-hour collections as an aid in diagnosis of coeliac disease
}

\author{
D. N. CHALLACOMBE, MARY GOODALL, H. GAZE, and G. A. BROWN \\ From the Institute of Child Health, University of Birmingham
}

\begin{abstract}
Challacombe, D. N., Goodall, M., Gaze, H., and Brown, G. A. (1975). Archives of Disease in Childhood, 50, 779. Urinary 5-hydroxyindoleacetic acid in 8-hour collections as an aid in diagnosis of coeliac disease. 8-hour urine excretions of 5-hydroxyindoleacetic acid (5-HIAA) were measured in 18 children with coeliac disease before treatment and the results expressed as $\mu \mathrm{g} 5-\mathrm{HIAA} / \mathrm{mg}$ creatinine. Similar measurements were made on urine collections from an agematched control group of 24 children. Significantly higher values of 5-HIAA excretion were found in children with untreated coeliac disease. Measurement of the 5-HIAA: creatinine ratio in 8-hour urine collections is therefore proposed as an aid in the diagnosis of coeliac disease.
\end{abstract}

In an earlier communication (Challacombe et al., 1972), the excretion of 5-hydroxyindoleacetic acid (5-HIAA) and creatinine was measured in 24-hour urine collections from children with untreated coeliac disease and from an age-matched control group. The results were expressed as $\mu \mathrm{g}$ 5-HIAA/ $\mathrm{mg}$ creatinine. Significantly higher values were found in patients with untreated coeliac disease, when compared with the control group. After withdrawal of gluten from the diet, 5-HIAA excretion fell in all 8 cases who were followed up.

Urine collection over complete 24-hour periods from infants and young children presents technical problems which would be reduced or eliminated by collection over a shorter time interval. A further study has therefore been made on 5-HIAA excretion in timed 8-hour collection periods in a second group of coeliac patients and age-matched controls. The data from the study are presented in this report.

\section{Materials and methods}

Patients. Urine collections were made from 18 children with coeliac disease (Table I). Diagnosis was confirmed in each case by showing a flat duodenal mucosal surface in tissue obtained by peroral biopsy and by remission of clinical symptoms after introduction of a gluten-free diet. Control data were obtained from 24 children of approximately equal age (Table I), who were in hospital for treatment or assessment but did not have gastrointestinal disease.

Received 8 January 1975.
Methods. All high serotonin-content foods (Erspamer, 1966) and all drugs were excluded from the diet for 24 hours before and during urine collection, which was made between 9.00 a.m. and 5.00 p.m. and passed directly into $10 \mathrm{ml}$ glacial acetic acid. Collections were stored at $-20^{\circ} \mathrm{C}$ until analysed. 5-HIAA was measured by a method based on that of Macfarlane et al. (1956), with improvements suggested by Mustala, Tuomisto, and Airaksinen (1964). Creatinine was measured by a standard Technicon AutoAnalyser alkaline picrate procedure (Methodology sheet $\mathrm{N}-11 \mathrm{~b}$ ) with a urine diluting step incorporated in the manifold.

\section{Results}

The 8-hour urinary 5-HIAA excretion values in patients with coeliac disease and the control group are shown in Fig. 1 and Table $I$. As in the previous study using 24-hour urine collections (Challacombe et al., 1972), the values of the coeliac 5-HIAA: creatinine ratios in the 8-hour collections were higher than the control results. When considered as a homogeneous group overlap of data occurred, but this was almost entirely due to an agerelated change in the ratio (Fig. 2). When coeliac results were compared with results from control children of similar age, only one was exceeded by a control value. Mean 5-HIAA: creatinine ratios for the coeliac and control groups were 23.2 and $9 \cdot 3$, respectively. Assessed by Student's ' $t$ ' test (Table II), the difference between means for the two groups was highly significant $(P<0.001)$. 
TABLE I

Urinary 5-HIAA, creatinine, and 5-HIAA: creatinine ratios in controls and patients with coeliac disease

\begin{tabular}{|c|c|c|c|c|c|c|}
\hline Case & Diagnosis & Age & Urine volume (ml) & 5-HIAA $(\mu g)$ & Creatinine (mg) & Ratio \\
\hline $\begin{array}{c}\text { Controls } \\
1 \\
2 \\
3 \\
4 \\
5 \\
6 \\
7 \\
8 \\
9 \\
10 \\
11 \\
12 \\
13 \\
14 \\
15 \\
16 \\
17 \\
18 \\
19 \\
20 \\
21 \\
22 \\
23 \\
\\
24 \\
\text { Coeliacs } \\
25 \\
26 \\
27 \\
28 \\
29 \\
30 \\
31 \\
32 \\
33 \\
34 \\
35 \\
36 \\
37 \\
38 \\
39 \\
40 \\
41 \\
42\end{array}$ & $\begin{array}{l}\text { Normal } \\
\text { Normal } \\
\text { Normal } \\
\text { Normal } \\
\text { Normal } \\
\text { Normal } \\
\text { Normal } \\
\text { Brain tumour } \\
\text { Normal } \\
\text { Congenital heart disease } \\
\text { Intussusception } \\
\text { Tonsillitis } \\
\text { Normal } \\
\text { Sickle cell anaemia } \\
\text { Normal } \\
\text { Normal } \\
\text { Normal } \\
\text { Cerebral palsy } \\
\text { Shigellosis } \\
\text { Malaria } \\
\text { Normal } \\
\text { Brain cyst } \\
\text { Tracheo-oesophageal } \\
\text { fistula } \\
\text { Normal }\end{array}$ & $\begin{array}{r}3 \mathrm{w} \\
1 \mathrm{~m} \\
2 \mathrm{~m} \mathrm{~m} \\
21 \mathrm{~m} \\
3 \mathrm{~m} \\
7 \mathrm{~m} \\
9 \mathrm{~m} \\
9 \mathrm{~m} \\
1 \mathrm{yr} 3 \mathrm{~m} \\
1 \mathrm{yr} 8 \mathrm{~m} \\
1 \mathrm{yr} 11 \mathrm{~m} \\
1 \mathrm{yr} 11 \mathrm{~m} \\
2 \mathrm{yr} 3 \mathrm{~m} \\
2 \mathrm{yr} 7 \mathrm{~m} \\
2 \mathrm{yr} 9 \mathrm{~m} \\
3 \mathrm{yr} 6 \mathrm{~m} \\
4 \mathrm{yr} 3 \mathrm{~m} \\
4 \mathrm{yr} 8 \mathrm{~m} \\
5 \mathrm{yr} 3 \mathrm{~m} \\
5 \mathrm{yr} 4 \mathrm{~m} \\
6 \mathrm{yr} 1 \mathrm{~m} \\
8 \mathrm{yr} \\
\\
8 \mathrm{yr} 3 \mathrm{~m} \\
8 \mathrm{yr} 3 \mathrm{~m} \\
\end{array}$ & $\begin{array}{r}61 \\
41 \\
121 \\
216 \\
173 \\
180 \\
85 \\
48 \\
330 \\
87 \\
355 \\
60 \\
117 \\
345 \\
13 \\
86 \cdot 5 \\
175 \\
85 \\
215 \\
1150 \\
187 \\
96 \\
\\
125 \\
122 \\
\end{array}$ & $\begin{array}{l}163 \\
108 \\
238 \\
421 \\
437 \\
458 \cdot 6 \\
500 \\
103 \\
550 \\
162 \\
270 \cdot 5 \\
347 \cdot 1 \\
388 \\
451 \cdot 8 \\
52 \cdot 4 \\
783 \\
610 \cdot 8 \\
665 \\
996 \cdot 3 \\
602 \cdot 4 \\
750 \\
267 \\
\\
448 \\
728 \\
\\
432 \\
630 \\
352 \cdot 3 \\
299 \cdot 4 \\
619 \cdot 3 \\
813 \cdot 5 \\
1001 \cdot 2 \\
689 \cdot 5 \\
847 \cdot 8 \\
916 \cdot 9 \\
378 \cdot 9 \\
449 \cdot 9 \\
813 \cdot 7 \\
1110 \cdot 0 \\
1739 \cdot 0 \\
920 \cdot 5 \\
1201 \cdot 9 \\
2074 \cdot 0\end{array}$ & $\begin{array}{r}10 \cdot 4 \\
7 \cdot 4 \\
19 \cdot 4 \\
23 \cdot 8 \\
31 \cdot 1 \\
30 \cdot 6 \\
28 \cdot 9 \\
17 \cdot 7 \\
95 \cdot 7 \\
26 \cdot 9 \\
34 \cdot 0 \\
50 \cdot 0 \\
36 \cdot 2 \\
59 \cdot 0 \\
4 \cdot 5 \\
64 \cdot 8 \\
134 \cdot 7 \\
75 \\
133 \\
144 \\
136 \cdot 5 \\
99 \\
\\
94 \\
145 \\
\end{array}$ & $\begin{array}{r}15 \cdot 7 \\
14 \cdot 6 \\
12 \cdot 3 \\
17 \cdot 7 \\
14 \cdot 0 \\
15 \cdot 0 \\
17 \cdot 3 \\
5 \cdot 8 \\
5 \cdot 7 \\
6 \cdot 0 \\
8 \cdot 0 \\
7 \cdot 0 \\
10 \cdot 7 \\
7 \cdot 7 \\
11 \cdot 6 \\
12 \cdot 0 \\
4 \cdot 5 \\
8 \cdot 9 \\
7 \cdot 5 \\
4 \cdot 2 \\
5 \cdot 5 \\
2 \cdot 7 \\
4 \cdot 8 \\
6 \cdot 0 \\
14 \\
14 \cdot 6 \\
12 \cdot 0 \\
34 \cdot 2 \\
14 \cdot 5 \\
18 \cdot 0 \\
33 \cdot 8 \\
38 \cdot 7 \\
16 \cdot 5 \\
30 \cdot 6 \\
33 \cdot 2 \\
27 \cdot 7 \\
17 \cdot 4 \\
16 \cdot 5 \\
16 \cdot 8 \\
16 \cdot 4 \\
14 \cdot 6\end{array}$ \\
\hline
\end{tabular}

TABLE II

Statistical analysis of results (Student's ' $t$ ' test)

\begin{tabular}{|c|c|c|c|c|}
\hline & $\begin{array}{l}\text { Volume } \\
\text { (ml) }\end{array}$ & $\begin{array}{c}\text { 5-HIAA } \\
(\mu g)\end{array}$ & $\begin{array}{c}\text { Creatinine } \\
\text { (mg) }\end{array}$ & Ratio \\
\hline $\begin{array}{l}\text { Controls }(n=24) \\
\text { Mean } \\
\text { SD } \\
\text { Coeliac disease } \\
(n=18) \\
\text { Mean } \\
\text { SD } \\
\text { Comparison of } \\
\text { means } \\
\text { t } \\
\text { P }\end{array}$ & $\begin{array}{c}186 \\
(225 \cdot 7) \\
180 \\
(117) \\
\\
0.1 \\
>0.9\end{array}$ & $\begin{array}{c}437.5 \\
(243 \cdot 8) \\
\\
849.4 \\
(469) \\
\\
\\
3.39 \\
<0.003\end{array}$ & $\begin{array}{c}62 \cdot 5 \\
(48) \\
\\
41 \cdot 2 \\
(38) \\
\\
1 \cdot 5 \\
>0.13\end{array}$ & $\begin{array}{c}9 \cdot 3 \\
(4 \cdot 5) \\
\\
23 \cdot 2 \\
(9) \\
\\
5 \cdot 8 \\
<0 \cdot 001\end{array}$ \\
\hline
\end{tabular}

Mean 8-hour urine volumes and their creatinine content were similar for the two groups. The differences between means were not significant. In both 8-hour and 24-hour collections of urine (Challacombe et al., 1972), the values of the ratio in both controls and coeliacs were shown to be high in early infancy and fell to lower values at approximately one year. They then appeared to fall more slowly over the remaining age range investigated. The ratios in the 8-hour collections in this control group tended to be lower than those in the 24-hour control collections. Ratios in the 8-hour and 24hour collections in patients with coeliac disease were, however, equally high. 


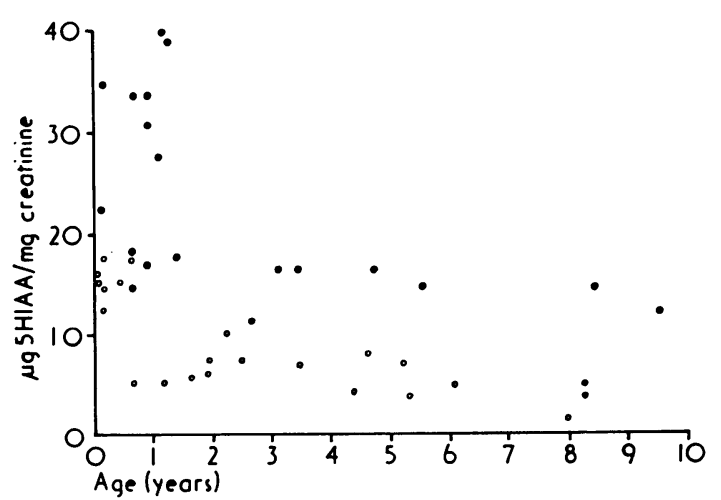

FIG. 1. - 5-HIAA:creatinine ratios in 8-hour urine collections from children with untreated coeliac disease (O) and age-matched controls ( 0 ).

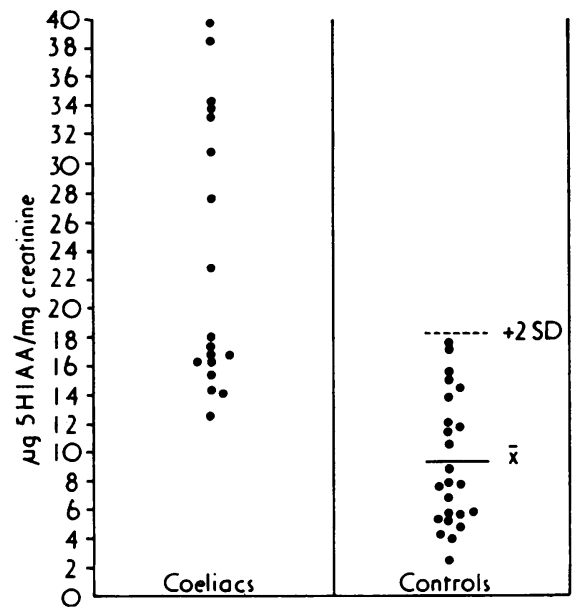

FIG. 2. - 5-HIAA:creatinine ratios in patients with untreated coeliac disease and controls, unrelated to age.

\section{Discussion}

Estimation of urinary excretion of 5-HIAA, expressed as a 5-HIAA:creatinine ratio, can be used as an aid in the diagnosis of coeliac disease using urine collections made over periods as short as 8 hours. Since the definitive diagnosis of coeliac disease can only be made by peroral small intestinal biopsy, 5-HIAA excretion may be used as a further indication in patients who do not have all the classical symptoms of coeliac disease but in whom the diagnosis is suspected.

Urine collections were made between 9.00 a.m. and 5.00 p.m., that being the period when the collection can be supervised most easily, either in the ward or at home. The period of collection must be consistent from patient to patient to avoid the influence of diurnal variation in 5-HIAA excretion which has been reported (Erspamer, 1966). The difference between 8-hour and 24hour 5-HIAA: creatinine ratios seen in the control data may be a consequence of diurnal variation of 5-HIAA excretion. This difference was not seen in the coeliac patients, suggesting that excretion is not only abnormally high, but that the diurnal excretion pattern is disturbed.

Factors that may be responsible for increased excretion of 5-HIAA in the urine in children with untreated coeliac disease have been discussed previously (Challacombe et al., 1972). An abnormality of argentaffin cell metabolism was proposed which may be stimulated or shown by the introduction of dietary gluten, producing increased quantities of 5-hydroxytryptamine and its metabolite 5-HIAA. Measurement of 5-HIAA excretion on children who have sibs with this disorder before the introduction of gluten into their diet may throw further light on this hypothesis.

We are indebted to Professor Charlotte $M$. Anderson for her advice, and to Mr. J. D. Leach of the Department of Mathematics, Statistics, and Operational Research, University of Exeter, for statistical help.

\section{REFERENCES}

Challacombe, D. N., Brown, G. A., Black, S. C., and Storrie, M. H. (1972). Increased excretion of 5-hydroxyindoleacetic acid in urine of children with untreated coeliac disease. Archives of Disease in Childhood, 47, 442.

Erspamer, V. (1966). Occurrence of indoleaklylamines in nature. 5-Hydroxytryptamine and Related Indolealkylamines, Handbuch der Experimentellen Pharmakologie, Vol. 19, pp. 132, 157. Ed. by V. Erspamer. Springer, Berlin.

Macfarlane, P. S., Dalgliesh, C. E., Dutton, R. W. Lennox, B. Nyhus, L. M., and Smith, A. N. (1956). Endocrine aspects of argentaffinoma, with special reference to the use of urinary 5-hydroxyindoleacetic acid estimations in diagnosis. Scottish Medical fournal, 1, 148.

Mustala, O. O., Tuomisto, J. J., and Airaksinen, M. M. (1964). A new modification for the determination of 5-hydroxyindoleacetic acid (5 HIAA) in urine. Scandinavian fournal of Clinical and Laboratory Investigation, 16, 655.

Correspondence to Dr. D. N. Challacombe, Children's Research Unit, Taunton and Somerset Hospital, Musgrove Park, Taunton, Somerset TA1 5DA. 